Acta Theriologica 35 (3-4): 215-224, 1990.

PL ISSN $0001-7051$

STUDIES ON THE EUROPEAN HARE. 40

\title{
Relation between haptoglobin polymorphism and the health status of brown hare populations in Poland
}

\author{
Janusz MARKOWSKI, Paweł OSMULSKI, Wirgiliusz DUDA, \\ Eugenia DYNER, Aleksander ŚWIATTECKI, \\ Magdalena UŁAŃSKA and Tomasz JANISZEWSKI
}

\begin{abstract}
Markowski J., Osmulski P., Duda W., Dyner E., Świątecki A., Ułańska M. and Janiszewski T. 1990. Relation between haptoglobin polymorphism and the health status of brown hare populations in Poland. Acta theriol. 35: 215-224.
\end{abstract}

During 1986- 1990 blood samples of 390 brown hares Lepus europaeus Pallas, 1778 were collected in 5 hunting areas in Poland. The blood cells were removed and the resulting serum or plasma protein were separated by electrophoresis in polyacrylamide gels. Three patterns of haptoglobins ( $\mathrm{Hp} 1-1,2-1,2-2)$ were identified on the basis of their mobilities in the gels. Microbiological samples of duodenum, rectum, gall bladder and lung were taken from 145 investigated specimens. The health status of the brown hares was classified in a two grade scale on the basis of infection state. The frequency of $\mathrm{Hp} 2-1$ was correlated with a health index of the populations in terms of the Spearman rank coefficient of correlation $(\rho=0.606 ; \mathrm{n}=12 ; p<0.05)$. Also a better survival of $\mathrm{Hp} 2-1$ phenotypes was showed. A better survival of the Hp 2-1 phenotypes was found. The observed correlation is discussed in terms of possible physiological roles of $\mathrm{Hps}$, especially in the hindrance of the action of active form of oxygen.

Department of Ecology and Vertebrate Zoology, University of Lódź, Banacha str. 12/16, 90-237 Łódź, Poland (JM, MU, TJ ), Department of Biophysics, University of Łódź, Banacha str. 12/16, 90 - 237 Łódź, Poland (PO, WD), Department of Microbiology, Teachers Training College, Żołnierska str. 14, 10-561 Olsztyn, Poland (ED, AŚ)

Key words: haptoglobin types, Lepus europaeus, selection

\section{Introduction}

The decrease in the abundance of the hunting stocks of small game in Poland which has been observed since the middle of the seventies (Sikorski 1987), has raised the question of the reason for such a decline. Particular attention has been paid to the brown hare Lepus europaeus Pallas, 1778, since it is the most important game species. The present program for the study of the brown hare conducted during 1986-1990 (Jezierski 1988), is a continuation of the former program organized at the end of the fifties and the beginning of the sixties in response to the first noticed big decline of the brown hare population (see Andrzejewski and Pielowski 1957). The present studies were expanded on microbiological and biochemical markers. The markers may eventually help in evaluation of the genetic structure of the populations, the possible selective pressures which act on the populations and may also provide a more detailed explanation of decrease in the abundance of the animals. 


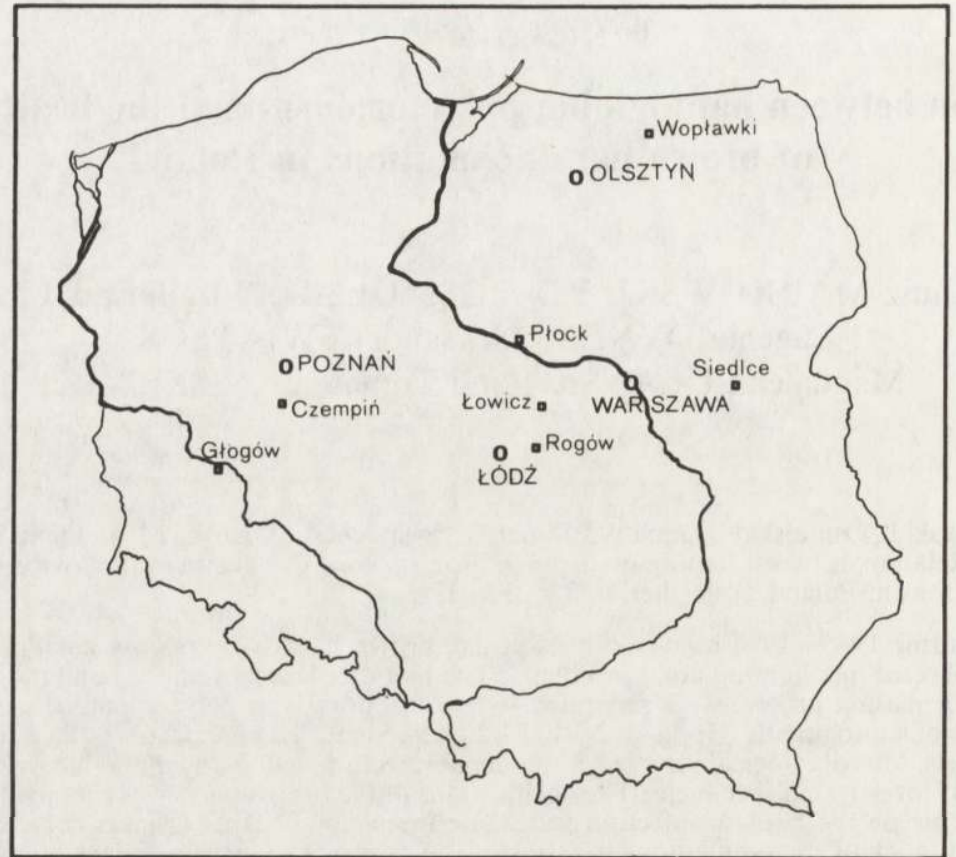

Fig.1. Geographic location of hunting areas, marked with squares.

Table 1. Characteristics of the hunting areas. Ex - experimental hunting area, LH - rented by local unit of Polish Hunting Association, LF-predominate large farming, SM-predominate small farming.

\begin{tabular}{lccccc}
\hline \multirow{2}{*}{$\begin{array}{l}\text { Hunting area } \\
\text { /Geographical location }\end{array}$} & $\begin{array}{c}\text { Total area, } \\
\text { ha }\end{array}$ & \multicolumn{3}{c}{ Land exploitation, \% } & Remarks \\
\cline { 3 - 5 } & & agricultural & forest & others & \\
\hline Wopławki /Mazurian Lakes & 4,903 & 85.0 & 2.0 & 13.0 & Ex, LF \\
Czempiń /Leszno Lakes & 15,000 & 90.0 & 7.0 & 3.0 & Ex, LF \\
Rogów /South - Mazovian & 13,000 & 74.0 & 23.0 & 3.0 & Ex, SM \\
Siedlce /South - Podlasie & 23,240 & 86.0 & 11.0 & 3.0 & LH, SM \\
Głogów /Dalków Upland & 2,048 & 85.0 & 13.5 & 1.5 & LH, SM \\
\hline
\end{tabular}

Haptoglobins (Hps), important glycoproteins of serum, were chosen as the first possible biochemical marker. The selection was based on the fact that haptoglobins play an important role in binding hemoglobin $(\mathrm{Hb})$ proteins and probably in other vital biochemical and immunological processes (Lisowska and Dobroszycka 1967, Cereblad 1979, Pagano et al. 1982, Sadrzadeh et al, 1984, Braughler and Hall 1989). The simple segregation of a pair of $\mathrm{Hp}^{1}$ and $\mathrm{Hp}^{2}$ alleles (Harris 1959) in brown hares in view of their physiological roles makes these proteins attractive for population studies. 


\section{Study area}

The investigations covered five hunting areas representing distinct physiographic regions of Poland (Fig. 1) with different agricultural and hunting exploitation. The basic data on the study areas are presented in Table 1 .

\section{Material and methods}

During 1986 - 1989, blood samples were collected of 390 brown hares in five hunting areas during four hunting seasons (Table 2). The individual hares were weighed, sexed and aged on the basis of the ossification stage of epiphyseal cartilage of the ulna (Stroh 1931). Subsequently, the blood samples were taken from the eye socket or the heart.

Two samples of blood were typically collected from each individual, one sample was anticoagulated with heparin ( 200 units of heparin per $\mathrm{ml}$ of $0.9 \% \mathrm{NaCl}$ ) and another was allowed to clot. The blood cells were removed with centrifugation and the resulting serum or plasma proteins were subsequently subjected to electrophoretical studies.

Electrophoresis was performed in vertical slab gels, about $0.5 \mathrm{~mm}$ thick. Generally, the Riggs' system (1981) was used with $7.5 \%$ acrylamide in Tris- $\mathrm{HCl}$ buffer $\mathrm{pH} 8.9$ (the resolving gel) and $4 \%$ acrylamide in Tris- $\mathrm{H}_{3} \mathrm{PO}_{4}$ buffer $\mathrm{pH} 7.2$ (the stacking gel). Usually the electrophoresises were run at current $60 \mathrm{~mA}$ for $4-5$ hrs. After separation was completed, the gels were stained for proteins with Coomassie Brillant Blue $\mathrm{G}-250$ and then destained with solution of methanol and acetic acid in water (14\% and $7 \%$, respectively). Chosen gels were stained for (pseudo) peroxidase activity of $\mathrm{Hp}-\mathrm{Hb}$ complex with $0.07 \%$ benzidine or $\mathrm{o}$-dianisidine in $1 \mathrm{~mol} /$ acetic acid (Riggs 1981). In the latter, hare $\mathrm{Hb}$ was added to the plasma or serum sample to the final concentration of about $0.1 \%$. The obtained protein patterns were analyzed with Opton densitometer at $\lambda=540 \mathrm{~nm}$.

The microbiological samples of rectum, duodenum, gall bladder and lung were taken from 145 specimens. Standard culture and staining methods were used for qualitative identification of pathogenic

Table 2. Number and frequency of $\mathrm{Hp}$ phenotypes and $\mathrm{Hp}^{\prime}$ allele in the hunting areas. Results of goodness-of-fit tests to the Hardy-Weinberg law are presented in the last column. Results of the homogenity test are: ${ }^{*} p<0.05 ;{ }^{* *} p<0.001$, $\chi^{2}=7.568 ;$ d.f. $=8 ; 0.3<p<0.5$.

\begin{tabular}{|c|c|c|c|c|c|c|}
\hline \multirow[b]{2}{*}{ Hunting area } & \multirow{2}{*}{$\begin{array}{r}\text { Total } \\
\text { sample }\end{array}$} & \multicolumn{3}{|c|}{ Haptoglobin types } & \multirow[b]{2}{*}{$\mathrm{Hp}^{\prime}$} & \multirow{2}{*}{$\begin{array}{c}\chi^{2} \\
\text { d.f. }=2\end{array}$} \\
\hline & & $1-1$ & $2-1$ & $2-2$ & & \\
\hline Wopławki & 44 & $\begin{array}{c}9 \\
(.204)\end{array}$ & $\begin{array}{c}26 \\
(.591)\end{array}$ & $\begin{array}{c}9 \\
(.204)\end{array}$ & .500 & 1.34 \\
\hline Czempiń & 68 & $\begin{array}{c}16 \\
(.236)\end{array}$ & $\begin{array}{c}43 \\
(.632)\end{array}$ & $\begin{array}{c}9 \\
(.132)\end{array}$ & & 5.27 \\
\hline Rogów & 178 & $\begin{array}{c}34 \\
(.191)\end{array}$ & $\begin{array}{c}114 \\
(.640)\end{array}$ & $\begin{array}{c}30 \\
.(.168)\end{array}$ & .511 & $19.85^{* *}$ \\
\hline Siedlce & 70 & $\begin{array}{c}12 \\
(.171)\end{array}$ & $\begin{array}{c}53 \\
(.757)\end{array}$ & $\begin{array}{c}5 \\
(.071)\end{array}$ & .550 & $19.62^{* *}$ \\
\hline Głogów & 30 & $\begin{array}{c}5 \\
(.167)\end{array}$ & $\begin{array}{c}22 \\
(.733)\end{array}$ & $\begin{array}{c}3 \\
(.100)\end{array}$ & $.530)$ & $6.74^{*}$ \\
\hline Total & 390 & $\begin{array}{c}76 \\
(.195\end{array}$ & $\begin{array}{c}258 \\
(.662)\end{array}$ & $\begin{array}{c}56 \\
(.144)\end{array}$ & & $41.07 * *$ \\
\hline
\end{tabular}



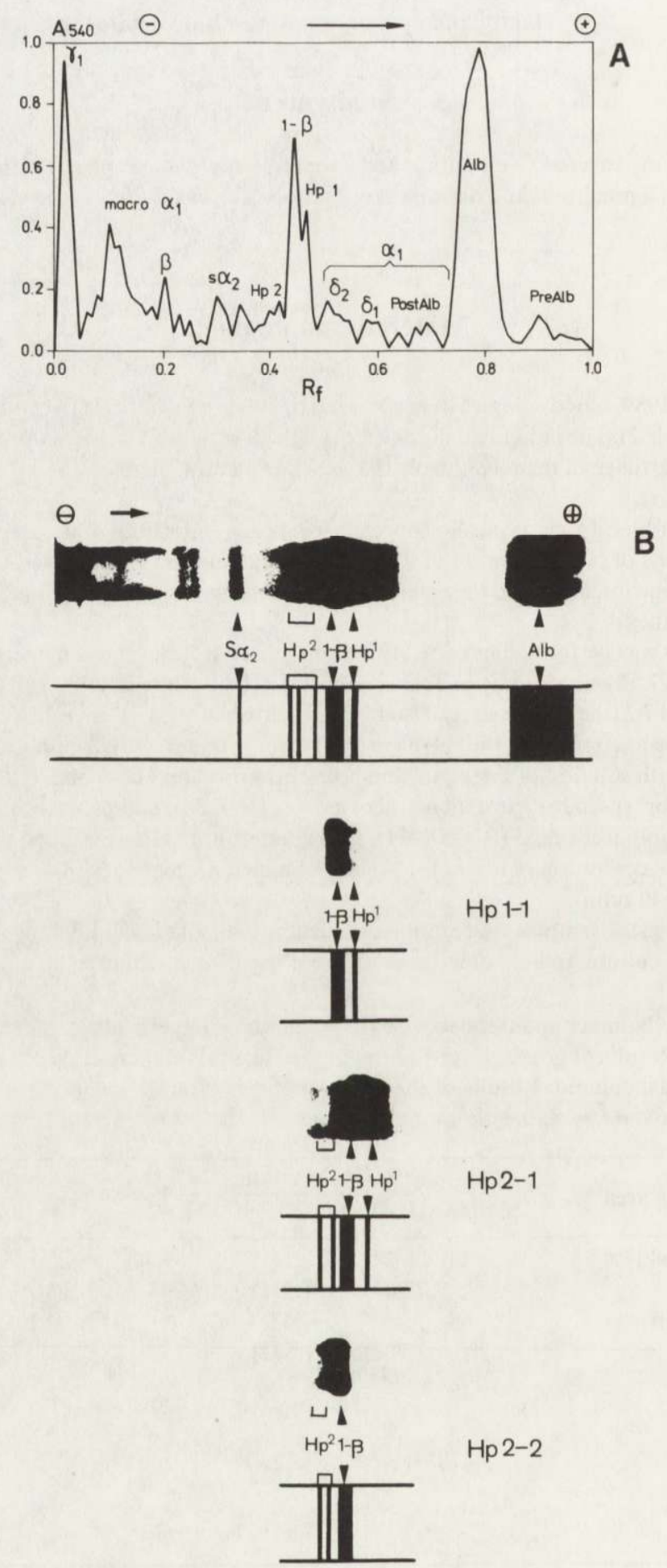

Fig. 2. Densitogram of electrophoretic separation of hare serum proteins (a) and pattern of haptoglobim phenotypes (b). 
Table 3. Frequency of heterozygotes $\mathrm{Hp} 2-1, \mathrm{Hp}^{1}$ allele and uninfected individuals in successive hunting seasons in the areas studied and $\rho$ values of the rank Spearman correlation between variables. $\rho_{\mathrm{Hpt} 2-1}=0.606, \rho_{\mathrm{Hp}} \mathrm{l}=0.360$.

\begin{tabular}{lrrrc}
\hline Hunting area & Season & HPT $2-1$ & Hp $^{1}$ & Uninfected \\
\hline Wopławki & $1986 / 87$ & .375 & .437 & .625 \\
& $1987 / 88$ & .667 & .500 & .583 \\
& $1988 / 89$ & .500 & .528 & .556 \\
& $1989 / 90$ & 1.000 & .500 & .667 \\
\hline Czempiń & $1988 / 89$ & .667 & .400 & .583 \\
& $1989 / 90$ & .630 & .648 & .652 \\
\hline Rogów & $1987 / 88$ & .667 & .474 & .600 \\
\hline Siedlce & $1987 / 88$ & .698 & .535 & 1.000 \\
& $1988 / 89$ & 1.000 & .500 & .930 \\
& $1989 / 90$ & .667 & .667 & .667 \\
\hline Głogów & $1988 / 89$ & .667 & .500 & .833 \\
& $1989 / 90$ & .778 & .556 & .733 \\
\hline
\end{tabular}

microorganisms of the following genera: Mycobacterium, Staphylococcus, Salmonella, Candida (Buchannan and Gibbons 1975). The levels of the serum antibody levels Brucella abortus, Leptospira sp. and Francisella tullarensis were also evaluated in the hare blood serum (Parnas and Wysocka 1957, Zwierz 1964). Two groups of brown hares were distinguished on the basis of the investigation of their microbiological and serological status: (1) the uninfected animals - these without infection symptoms of the organs investigated, with negative results for pathogens isolation and negative serological tests; (2) the infected animals - these with infection symptoms of the internal organs supported by isolation of the pathogens and positive serological tests. The populational index of health status was calculated as a frequency of the animals uninfected in the particular seasons for each population investigated (Table 3).

Chi-square statistics were used to test significant variations from the Hardy-Weinberg law and from the homogeneity. The association between qualitative variables was computed by Spearman's coefficient of rank correlation $(\rho)$.

\section{Results}

The densitometric analysis of patterns obtained after the electrophoretical separation of proteins in the polyacrylamide gels allowed us to distinguish eight main groups of protein bands of hare serum: prealbumins (prealb), albumin (alb), postalbumins (postalb), transferins $\left(\delta_{1}, \delta_{2}, 2-\beta, 1-\beta\right)$, haptoglobin (Hp), slow $\alpha_{2}$, lipoprotein $(\beta-\mathrm{Lp})$, immunoglobulins $(\alpha, \gamma)$ (Fig. 2). Three patterns of Hp bands (Fig. 2) were identified on the basis of their mobilities in the gels: Hp 1-1 shows a single, relatively fast-moving fraction in the front of the main transferrin band, $\mathrm{Hp}$ $2-2$ exhibits the series of slower bands moving behind the main transferrin band, and $\mathrm{Hp} 2-1$ the pattern with properties close to the $\mathrm{Hp} 1-1$ band and $\mathrm{Hp} 2-2$ like bands (Markowski et al. 1989, P. Osmulski et al., in prep.). 
Table 4. Frequency of heterozygotes $\mathrm{Hp} 2-1$ and percentage of hares free of coccidiosis in the successive hunting seasons in the Rogów area. * M. Wasilewski (pers. comm.).

\begin{tabular}{lcc}
\hline Season & Hp 2-1 & $\begin{array}{c}\text { Coccidiosis } \\
\text { free, \%* }\end{array}$ \\
\hline $1986 / 87$ & 0.529 & 57.2 \\
$1987 / 88$ & 0.604 & 69.1 \\
$1988 / 89$ & 0.638 & 81.9 \\
$1989 / 90$ & 0.644 & 85.2 \\
\hline
\end{tabular}

Although there are no data concerning heredity of hare Hps, we decided to adopt a common pattern found in all previous mammalian investigations (also in a rabbit). On this basis the $\mathrm{Hp} 1-1$ and $\mathrm{Hp} 2-2$ were classified as homozygotes and the $\mathrm{Hp} \mathrm{2-1}$ type as heterozygote which makes a simple codomination system (see discussion for details). The described system of Hps showed no statistically significant differences between populations investigated $\left(\chi^{2}=\right.$ $7.568 ; d . f .=8 ; 0.3<p<0.5)$. The heterozygote frequencies were more variable than those of homozygotes. The highest frequency of heterozygotes was found in the Siedlce hunting area and the lowest in the Wopławki area (Table 2). The differences between the number of Hp phenotypes observed and the number expected according to the Hardy-Weinberg equilibrium, were statistically significant in the Rogów, Siedlce and Głogów hunting areas (Table 2).

In the all hunting areas but one, where an increase of heterozygote frequencies was observed (the Rogów area), no statistical differences were found in $\mathrm{Hp}$ frequencies between successive hunting seasons (Table 3). The groups of uninfected hares were characterized by a high domination of heterozygotes $(74 \%)$. The difference between observed and expected number of individuals with the distinguished $\mathrm{Hp}$ phenotypes was statistically significant in the group $\left(\chi^{2}=25.11 ;\right.$ d.f. $\left.=2 ; p<0.001\right)$. However, the difference between observed and expected numbers was not statistically significant in the group of the infected hares $\left(\chi^{2}=0.83 ;\right.$ d.f. $\left.=2 ; 0.5<p<0.7\right)$ (Table 5). The relation between the high heterozygote frequency and the population health status was statistically significant when calculated with the rank Spearman correlation coefficient, for the data grouped by the seasons and areas $(\rho=0.606 ; \mathrm{n}=12 ; p<0.05)$. However, such correlation for the $\mathrm{Hp}^{\prime}$ allele frequency was not statistically significant $(\rho=0.360$; $\mathrm{n}=12 ; p>0.05$ ) (Table 3 ). The positive relation between the percentage of heterozygotes and the percentage of coccidiosis-free hares was indicated in four successive hunting seasons in the Rogów area showed (Table 4).

\section{Discussion}

The Hp patterns obtained after the electrophoretical separation of the serum or plasma proteins in the polyacrylamide gels represented a typical configuration found in all mammals investigated to the present time (Harris 1959, Arenals and Rodriguez 1960, Beckman and Cedermark 1960, Chiao and Dray 1969, Cereblad 1979, and others).

The observed number of $\mathrm{Hp}$ heterozygotes and gene frequencies for the $\mathrm{Hp}^{1}$ and $\mathrm{Hp}^{2}$ around the value of 0.5 in the investigated hare populations strongly suggested a codominate expression of genes. The concept was further supported by results of 
progeny tests of rabbits with all possible matings. It was found in this case that $\mathrm{Hp}$ genotypes were controlled by a pair of allelic genes at an autosomal locus (Chiao and Dray 1969). The similar investigations on related and unrelated human populations and also ape populations gave identical results concerning heredity of $\mathrm{Hp}$ genes (Mäkelä et al. 1960, Harris 1964 and references cited therein, Maeda and Smithies 1986, Borensen et al. 1987, and others). On this basis, the simple codomination system of heredity of the hare Hp was adopted. Moreover, Harris (1964) emphasized the stability of the encoded $\mathrm{Hp}$ alleles during an ontogenetic development. This finding allowed the use of $\mathrm{Hp}$ as a genetic marker of specimens and suggested the study of frequency changes of the $\mathrm{Hp}$ types at population level. The observed differences in frequency of haptoglobin phenotypes in the studied populations, although not statistically significant with respect to their geographical distribution, turned most of our attention to the health status as the one of the most important factors influencing the function of population. We have already emphasized an increase of the heterozygote number in the animals from the second age class (6 to 12 months old) when compared to the first age class (up to 6 months old) and a negligible increase of the heterozygotes at the end of the hunting season in the Rogów area (J. Markowski et $a l$, in prep.). According to the codominate type of genetic determination of Hps, the equal distribution of homo- and heterozygotes should be expected. However, such a picture is valid only for a population under equilibrium conditions. Since the observed number of $\mathrm{Hp}$ phenotypes is not statistically different from the number expected in the class of the infected hares, it seems unlikely to anticipate a distinct situation in the class of the uninfected animals. As a consequence, the domination of heterozygotes observed in the latter class testifies to heterogeneity of the class. It seems that in addition to those animals which were never infected, this class contains recoverees among which the heterozygotes dominate. This shifts the genetic equilibrium out of the distribution of $\mathrm{Hp}$ phenotypes expected on the basis of the Hardy-Weinberg law.

The above conclusion is supported by the similar distribution of the $\mathrm{Hp}$ phenotypes observed in a class of the animals with protozooan infection-coccidiosis. It is a typical illness of young hares, by which almost all specimens are infected. The surviving individuals become immunized against this pathogene (Braunschweig 1976). The group of coccidiosis-free animals consists of mainly recoveers, and again, a domination of the heterozygotes was observed in this group (Table 4). The physiological role of $\mathrm{Hp}$ is still puzzling. It is known that its main function on a biochemical level is to bind hemoglobin freed out of erythrocytes to prevent undue loss of iron. It is also an acute-phase protein (Putman 1975). Free Hb exhibits high pseudoperoxidase activity, so it catalyzes decomposition of hydrogen peroxide followed by generation of potentially dangerous free radicals like superoxide or hydroxyl radicals (Gutteridge 1987). This in turn leads to deactivation or destruction of vital components of an organism, mainly proteins, nucleic acids and lipids. On the other hand, $\mathrm{Hb}$ in complex with $\mathrm{Hp}$ is much less reactive and, moreover, is much more 
quickly eliminated from the blood circulation system. However, the rate of the complex elimination strongly depends on the molecular weights of the molecule. A larger molecule has a slower elimination rate. $\mathrm{Hp}^{1}$ is a molecule of relatively low molecular weight in comparison with $\mathrm{Hp}^{2}$. The latter creates series of large linear polymers (Javid 1978) which leads to its slow elimination and possible prolonged exposure of an organism to the action of free radicals (Braughler and Hall 1989 and references cited therein). The $\mathrm{Hp}^{1}$ and $\mathrm{Hp}^{2}$ molecules also create mixed aggregates with lower molecular weight in comparison with $\mathrm{Hp}^{2}$ alone. It is important to realize that each type of polymer can bind only one molecule of $\mathrm{Hb}$ (one $\alpha \beta$ dimer on each end) but with somewhat lower efficiency in the case of $\mathrm{Hp}^{2}$ (Putnam 1975).

In response to infection, specific biochemical and immunological processes are activated in an organism. One of the most important is an increase of phagocytic activity of blood leukocytes. This, in turn, leads to the higher production of free radicals (Lowrie and Aber 1977, Beckmann and Flohe 1981 and references cited therein). On the other hand, the infection enhances a process of hemolysis and increases the level of free $\mathrm{Hb}$. On this basis, it seems possible that specimens possessing Hp 2-1 should show better adaptation than homozygotes. Moreover, there is a suggestion that the individuals possessing the $\mathrm{Hp} 2-2$ phenotype were predisposed to some illnesses, for example in human population to myocardial infract, epilepsy and rheumatoid arthritis (Chapelle et al. 1982, Panter et al. 1985, Rantapää Dahlqvist and Fröhlander 1985). However, we could find no statistically significant deviation of the Hp phenotypic distribution according to the Hardy-Weinberg low in the group of infected hares (Table 5). Our findings strongly support a connection between the health status and the Hp phenotype. Although, in the case of

Table 5. Numbers of observed Hp phenotypes and their frequencies in the uninfected and infected hares (number of the Hp phenotypes expected under the assumption of the Hardy-Weinberg law are given in brackets). ${ }^{* * *} p<0.0005, d . f .=2$.

\begin{tabular}{|c|c|c|c|}
\hline \multirow{2}{*}{ Haptoglobin types } & \multicolumn{2}{|c|}{ Health status } & \multirow{2}{*}{ Total } \\
\hline & Uninfected & Infected & \\
\hline $1-1$ & $\begin{array}{l}16^{(28.37)} \\
0.158\end{array}$ & $\begin{array}{l}9^{(10.48)} \\
0.204\end{array}$ & 25 \\
\hline $2-1$ & $\begin{array}{l}75^{(50.32)} \\
0.742\end{array}$ & $\begin{array}{l}25^{(21.99)} \\
0.568\end{array}$ & 100 \\
\hline $2-2$ & $\begin{array}{l}10^{(22.31)} \\
0.090\end{array}$ & $\begin{array}{l}10^{(11.53)} \\
0.227\end{array}$ & 20 \\
\hline Total & 101 & 44 & 145 \\
\hline $\mathrm{Hp}^{1}$ & 0.530 & 0.488 & \\
\hline$\chi_{\mathrm{HpH}-\mathrm{W}}^{2}$ & $25.11^{\cdots}$ & 0.83 & \\
\hline
\end{tabular}


the investigated hare population, Hp phenotype does not change susceptibility for the infections studied, but does change the possibility of recovery success.

Concluding, it appears that Hps may seriously influence populational processes of hare, and they may be used as a valuable marker for these processes.

Acknowledgements: The authors wish to thank the local hunters in Poland and students of: Warsaw Agriculture University, Łódź University, Siedlce Teachers Training College and Olsztyn Teachers Training College for their help in sampling. We are also indebted to Professors W. Jezierski, A. Kryński and Dr. W. Wasilewski for giving access to populational data on hares. This study was supported from the grant $\mathrm{PR}-\mathrm{II}-17$

\section{References}

Andrzejewski R. and Pielowski Z. 1957. O konieczności pogłębienia badań populacyjnych nad zającem (Lepus europaeus, Pall.). Ekol. Pol. B, 3: 293-299.

Arenals T. and Rodriguez de M. L. G. 1960. Haptoglobins in monkeys. Nature 185: 325-326.

Braunschweig V. A. 1976. Wildkrankheiten. Landbuch Verl. Hannover: 1-146.

Beckman L. and Cedermark G. G. 1960. Haptoglobin types in Macaca irus. Nature 186: 643-644.

Beckmann R. and Flohe L. 1981. The pathogenic role of superoxide radicals in inflammation: efficacy of exogenous superoxide dismutase. Bull. europ. Physiopath. resp. 17: 275-285.

Braughler J. M. and Hall E. D. 1989. Central nervous system trauma and stroke. I. Biochemical considerations for oxygen radical formation and lipid peroxidation. Free Radical Biol. \& Medicine 6: $289-301$.

Buchanan R. E. and Gibbons N. E. 1975. Bergey's manual of determinative bacteriology. The Williams and Wilkins Company, Baltiomore: 1-1268.

Cereblad G. 1979. Plasma proteins involved in haem metabolism and in transport of metals, hormones and vitamins. [In: Plasma proteins. H. Blombäck and B. Hanson, eds]. John Wiley and Sons, Chichester, New York, Brisbane, Toronto: 102-106.

Chapelle J. P., Albert A., Smeets J. P., Heusgham C. and Kulbertus H.E. 1982. Effect of the haptoglobin phenotype on the size of a myocardial infract. New Engl. J. Med. 161: 457-754.

Gutteridge J. M. C. 1987. The antioxidant activity of haptoglobin towards haemoglobin-simulated lipid peroxidation. Acta Biochim. Biophys. 917: 219-223.

Harris H. 1959. Human biochemical genetics. Cambridge Univ. Press, Cambridge: 1-328.

Javid J. 1978. Human haptoglobins. Curr. Top. Haematol. 1: 151-159.

Jezierski W. 1988. Lagomorph programme in Poland. Lagomorph Newslett. 8: 11-12.

Lowrie D. B. and Aber V. R. 1977. Superoxide production by rabbit pulmonary alveolar macrophages. Life Sci. 21: $1575-1584$.

Maeda N. and Smithies O. 1986. The evolution of multigene families in human haptoglobin genes. Ann. Rev. Genet. 20: 81-101.

Markowski J., Osmulski P., Duda W., Ułańska M. and Janiszewski T. 1989. Haptoglobin variability of brown hare population in Poland. Abstract of papers and posters. Fifth International Theriological Congress, 22-29 August 1989, Roma: 187.

Mäkelä O., Renkonen O. V. and Salonen E. 1960. Electrophoretic patterns of haptoglobins in apes. Nature 185: $852-853$.

Pagano M., Nicola M. M. and Engler R. 1982. Inhibition of cathepsin L and B by haptoglobin, the haptoglobin-hemoglobin complex and asialohaptoglobin. "In vitro" studies in the rat. Can. J. Biochem. 60: 631-638. 
Panter S. S., Sadrzadeh S. M. H., Hallaway P. E., Haines J. L., Anderson V. E. and Eaton J. W. 1985. Hypohaptoglobinemia associated with familial epilepsy. J. Exp. Med. 161: $748-754$.

Parnas J., Rozowski T. and Wysocka F. 1975. Tularemia. PZWL. Warszawa: 1-332.

Putnam F. M. 1975. Haptoglobins. [In: The plasma proteins. F. M. Putnam, ed.] vol. II. Academic Press, New York: 2-50.

Rantapää Dahlqvist S. and Fröhlander N. 1985. Haptoglobin groups and rheumatoid arthritis. Hum. Hered. 35: 207-211.

Riggs A. 1981. Preparation of blood hemoglobins of vertebrates. [In: Methods in enzymology. t. 76. Hemoglobins. E. Antonini, L. Rossi-Bernardi and E. Chiancone, eds]. Academic Press, New York: $5-29$.

Sadrzadeh S. M., Graf E., Panter S. S., Hallway P. E. and Eaton J. W. 1984. Hemoglobin, a biological Fenton reagent. J. Biol. Chem. 259: $14354-14356$.

Sikorski J. 1987. Kierunki rozwoju gospodarki łowieckiej. Łow. pol. 11: 4-7.

Socha W. 1971. Genetyka grup krwi i białek surowicy krwi. [In: Problemy genetyki medycznej. E. F. Dawidenkowa, W. P. Efroimson and A. Horst, eds]. PZWL, Warszawa: 163-196.

Zwierz J. 1964. Leptospirozy. PZWL, Warszawa: 1-392.

Received 12 January 1990, accepted 27 February 1991. 